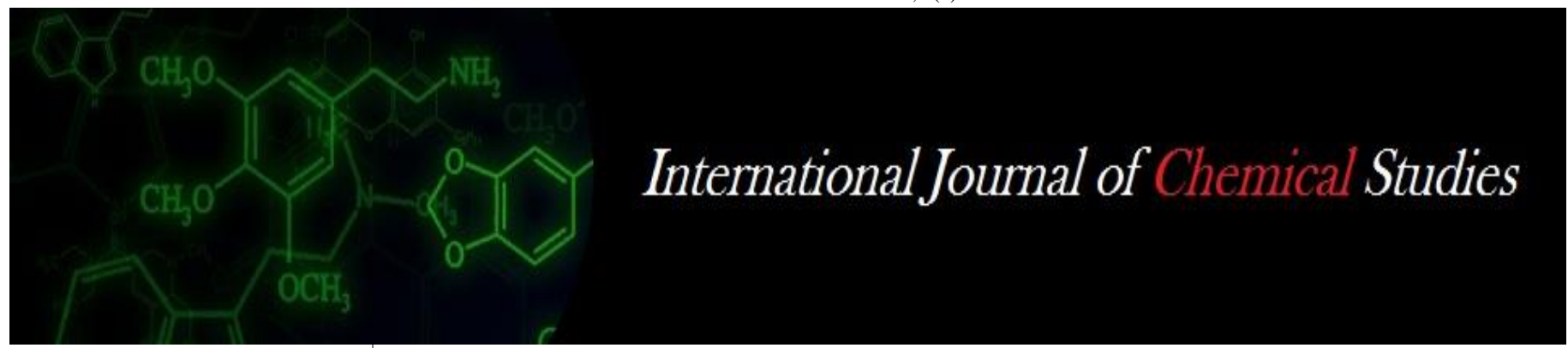

P-ISSN: 2349-8528

E-ISSN: 2321-4902

www.chemijournal.com

IJCS 2020; 8(6): 1914-1916

(C) 2020 IJCS

Received: 12-09-2020

Accepted: 19-11-2020

Gurmehakdeep Singh Department of Agriculture, Khalsa College Amritsar,

Punjab, India

\section{Amandeep Kaur}

Department of Agriculture,

Khalsa College Amritsar,

Punjab, India

\section{Navjot Singh Dhillon}

Department of Agriculture,

Khalsa College Amritsar,

Punjab, India
Corresponding Author: Gurmehakdeep Singh Department of Agriculture, Khalsa College Amritsar, Punjab, India

\section{Response of integrated nutrient management on cucumber (Cucumis sativus L.) hybrid under polyhouse conditions}

\author{
Gurmehakdeep Singh, Amandeep Kaur and Navjot Singh Dhillon
}

DOI: https://doi.org/10.22271/chemi.2020.v8.i6aa.11047

\begin{abstract}
The research was conducted at Vegetable Research Farm, Department of Agriculture, Khalsa College Amritsar, Punjab to study the response of integrated nutrient management on yield and its related characters of cucumber (Cucumis sativus L.) hybrid under protected environment. Experiment was laid out in Randomized Block Design comprising of six treatments replicated thrice. The effect of vermicompost, inorganic and bio fertilizers in different combinations on yield and related characters of cucumber were studied. Plants fertilized with RDF + vermicompost @ $5 \mathrm{t} / \mathrm{ha}+$ Azotobacter $@ 5 \mathrm{Kg} / \mathrm{ha}+$ PSB @ $5 \mathrm{Kg} / \mathrm{ha}$ shown maximum value for yield and related traits and it is the best integrated nutrient management approach for protected cultivation of cucumber under Punjab conditions.
\end{abstract}

Keywords: Cucumber, polyhouse, integrated nutrient management, yield

\section{Introduction}

Cucumber (Cucumis sativus L.) is a member of the gourd family cucurbitaceae, which comprises of 117 genera and 825 species in warmer parts of the world (Gopalakrishnan 2007) ${ }^{[1]}$. It is thought to be one of the oldest vegetable crops and has been found in cultivation for over 3000 years in India (Tekale et al. 2014) ${ }^{[2]}$. It grows best under condition of high light intensity, humidity, moisture, temperature and fertilizer, being a warm season vegetable. Cucumber is a thermophilic and frost susceptible species growing best at temperature above 20 ${ }^{\circ} \mathrm{C}$.

At present, cultivation of cucumber in open fields is a wide spread practice in Punjab. But, the cucumber crop grown in open fields during spring summer or rainy autumn seasons is exposed to various abiotic (low temperature and unpredictable weather) and biotic (red pumpkin beetle, fruit fly and incidence of downy/powdery mildew) stresses and therefore, it is not possible to produce high quality cucumber in terms of size, shape, colour and free from diseases and pests as compared to cucumber produced under protected environment (Dhillon et al. 2017) [3]. Therefore, it makes imperative to take up cucumber cultivation under polyhouse particularly, when production of cucumber is done for export purpose.

Although it is one of the major vine crop grown, its yield is quite low (Jilani et al. 2009) ${ }^{[4]}$. Increase in cucumber production can be achieved either bringing more area under its cultivation or by adopting improved varieties and better cultural practices. The second approach is more often preferred and among various cultural practices, fertilizer application is one of the quickest and easiest ways of increasing the yield per unit area under cucumber (Natsheh and Mousa 2014) ${ }^{[5]}$. The correct quantity of fertilizers application not only increases the yield but also improve the quality.

Intensive use of only chemical fertilizers to achieve high production alters the soil fertility and increase the cost of production as well. Presently, integrated nutrient management (INM) is gaining more importance as it ensures scientific management of soil health for optimum growth, yield and quality of crops in a sustainable manner. Integrated nutrient management (INM) system refers to the balanced use of chemical fertilizers in combination with organic manures, crop residues, bio fertilizers and other biological sources (Thriveni et al. 2015) ${ }^{[6]}$. The integration of different nutrient sources enhances growth, yield and quality attributing characters in vegetables as compared with sole application of recommended dose of chemical 
fertilizers (Kumar et al. 2018) ${ }^{[7]}$. Hence, integrated supply of nutrients through organic, inorganic and bio fertilizers is the need of the hour for sustainable productivity and to maintain better soil health. Hence, there is a need to standardize the integrated nutrient management practices for cucumber growing under polyhouse condition to get early yield and higher productivity and quality of produce under Indian conditions.

\section{Materials and Methods}

The experiment was conducted at the Vegetable Research Farm, Department of Agricultural, Khalsa College, Amritsar in 2019 under a naturally ventilated polyhouse. Seeds of parthenocarpic $F_{1}$ hybrid Kingstar were sown in plastic plug trays, by using soilless media having cocopeat, perlite and vermiculite in the ratio of $3: 1: 1$, respectively inside the growth chamber to get healthy and disease free seedlings of cucumber. The seedlings were ready for transplanting after 28 days of seed sowing. The experiment was laid out in Randomised Block Design (RBD) comprising of six treatments replicated thrice.

Treatment of cucumber plants with the different combinations of organic, inorganic and bio fertilizers has been done in this experiment with the view of standardization of suitable nutrient combination under integrated nutrient management practice for growing cucumber under protected conditions. Total six treatments viz; $\mathrm{T}_{1}(\mathrm{RDF}+$ Azotobacter @ $5 \mathrm{Kg} / \mathrm{ha})$, $\mathrm{T}_{2}$ (RDF + PSB @ $\left.5 \mathrm{Kg} / \mathrm{ha}\right), \mathrm{T}_{3}$ (RDF + Vermicompost @5 t/ha), T4 (RDF+ Azotobater @5 Kg/ha + PSB @ 5 Kg/ha), T5 (RDF + Vermicompost @5 t/ha + Azotobacter @5 Kg/ha + PSB @ $5 \mathrm{Kg} / \mathrm{ha}$ ), T6 (Control). Vermicompost was added and mixed thoroughly in the soil at the time of bed preparation to the specific plots one week before transplanting. The pit application of bio fertilizers was done later at the time of transplanting of seedlings in relevant treatment combination plots. Seedlings of uniform growth pattern were selected randomly per treatment and transplanted at $70 \mathrm{~cm} \times 30 \mathrm{~cm}$ spacing. Inorganic fertilize i.e. nitrogen, phosphorus and potassium was applied through fertigation. Fertigation was done 3 weeks after transplanting and was applied at the recommended rate of NPK thrice a week through water soluble fertilizers.
The observations were recorded on five plants taken randomly for the characters viz; days to anthesis of first female flowering, days to first picking, fruit length $(\mathrm{cm})$, girth $(\mathrm{cm})$, weight $(\mathrm{g})$, number of fruits per plant, fruit yield per plant $(\mathrm{Kg})$ and yield per plot $(\mathrm{Kg})$. The data pertaining to the present investigation were statistically analyzed using the standard procedures of the Randomized Block Design (RBD). The treatment effects were tested at $5 \%$ level of significance.

\section{Results and Discussions}

The organic, inorganic and bio fertilizers had the significant effect on various yield and yield attributing parameters of cucumber. Table 1 depicted that the plants under treatment $\mathrm{T}_{5}$ took minimum number of days for anthesis of first female flower and days to first picking. Least number of days to anthesis of first female flower and days to first picking in $\mathrm{T}_{5}$ may be attributed to the fact that the judicious integration of organic manure with inorganic and bio fertilizers are capable of supplying optimum level of nutrient along with favorable growing media efficient in inducing early flowering in the very treatment. These results are in close conformity with the experimental findings of Singh et al. (2018) ${ }^{[8]}$ in cucumber. First picking of fruit is associated with the anthesis of the flower. Lesser the number of days to taken to anthesis of first female flower, minimum days it will take to first picking. Presence of organic acids, enzymes and phytohormones like auxins and other growth regulators in vermicompost play a key role for early fruiting. The results are in consonance with the findings of Moharana et al. (2017) ${ }^{[9]}$ in cucumber.

Yield attributing parameters like fruit length, girth and weight show maximum value in case of combined treatment of RDF + Vermicompost + Azotobacter + PSB. Higher fruit length, girth and weight may be because of the easy accessibility of nutrients to plants through integration of bio fertilizers like Azotobacter with inorganic fertilizers and organic manure which has proven to enhance the process of nitrogen fixation in the soil. It has further resulted in the production of amino acids which are the building blocks of protein capable of hastening the multiplication of cells manifesting maximum fruit length, girth and weight. The findings are in congruence with results provided by Jilani et al. (2009) ${ }^{[4]}$ and Singh (2016) ${ }^{[10]}$ in cucumber.

Table 1: Response of integrated nutrient management on yield parameters of cucumber

\begin{tabular}{|c|c|c|c|c|c|c|c|c|}
\hline Treatments & $\begin{array}{l}\text { Days to anthesis of } \\
\text { first female flower }\end{array}$ & $\begin{array}{c}\text { Days to } \\
\text { first pick }\end{array}$ & $\begin{array}{l}\text { Fruit length } \\
(\mathrm{cm})\end{array}$ & \begin{tabular}{|c|} 
Fruit girth \\
$(\mathrm{cm})$
\end{tabular} & \begin{tabular}{|c|}
$\begin{array}{c}\text { Fruit weight } \\
(\mathrm{g})\end{array}$ \\
\end{tabular} & $\begin{array}{c}\text { Number of } \\
\text { fruits per plant }\end{array}$ & $\begin{array}{c}\text { Yield per plant } \\
(\mathrm{Kg})\end{array}$ & $\begin{array}{c}\text { Yield per plot } \\
(\mathrm{Kg})\end{array}$ \\
\hline $\mathrm{T}_{1}$ & 22.97 & 42.87 & 14.96 & 11.80 & 122.57 & 14.87 & 1.82 & 83.72 \\
\hline $\mathrm{T}_{2}$ & 23.93 & 43.87 & 14.35 & 10.83 & 118.70 & 13.57 & 1.61 & 74.06 \\
\hline $\mathrm{T}_{3}$ & 20.97 & 39.27 & 16.09 & 13.14 & 141.33 & 18.70 & 2.64 & 121.44 \\
\hline $\mathrm{T}_{4}$ & 21.77 & 41.40 & 15.40 & 12.47 & 130.63 & 16.00 & 2.09 & 96.14 \\
\hline $\mathrm{T}_{5}$ & 19.70 & 37.63 & 17.43 & 14.35 & 150.27 & 21.93 & 3.30 & 151.88 \\
\hline $\mathrm{T}_{6}$ & 24.90 & 45.63 & 13.83 & 9.75 & 110.77 & 11.00 & 1.22 & 56.10 \\
\hline CD (5\%) & 0.54 & 0.79 & 0.69 & 0.20 & 4.08 & 1.34 & 0.51 & 7.12 \\
\hline
\end{tabular}

Cucumber plants fertilized with $\mathrm{T}_{5}$ produce more number of fruit per plant. Comparatively better growth in terms of increased vine length, production of female flower at lower node, higher number of nodes per plant and more number of female flowers might have been said to be reflected in significantly increasing number of fruits per vine in the treatment $\mathrm{T}_{5}$. The increased vine length and more axillaries branches had maximized the fruiting buds on a vine and ultimately number of fruits per vine was increased. These findings are in conformity with the findings of Arun and Kumar (2014) ${ }^{[11]}$ and Prabhu et al. (2006) ${ }^{[12]}$.
The ultimate goal of any research program is to achieve maximization of marketable yield. This is also the key factor in adoption or rejection of a variety by the farmer. The fruit yield per plant and fruit yield per plot ranged from 1.22 to $3.30 \mathrm{Kg}$ and 56.10 to $151.88 \mathrm{Kg}$, respectively. The maximum value for these traits was noticed in $\mathrm{T}_{5}$. The higher fruit yield per plant and comparatively better performance of $\mathrm{T}_{5}$ over the all other treatments could be ascribed to its better performance in yield contributing characters such as fruit length, girth, weight and number of fruits per plant. Higher yield per plant may be due to the role of biological 
components like Azotobacter in faster nitrogen fixation and PSB in phosphorus solubilisation in combination with the quick release of available nutrient from the inorganic fertilizers coupled with micronutrients and vitamins from organic manure like vermicompost. More number of fruits per plant and fruit weight per plant ultimately resulted in more fruit yield per plant. Present findings are in conformity with the reports of Choudhari and More (2002) ${ }^{[13]}$ in cucumber. Yield per plant is one of the most important factor which attributes to the yield per unit area. The possible reason behind maximum number of fruits resulting in highest fruit yield per plot in $T_{5}$ may be attributed to the minimum number of days taken for female flower emergence, allowing maximum number of female flowers throughout the life span leading to more number of fruits which has ultimately contributed to the highest yield in $\mathrm{T}_{5}$. These findings are in congruence with the findings of Patle et al. (2018) ${ }^{[14]}$ and Singh et al. (2018) ${ }^{[8]}$ in cucumber.

\section{Conclusion}

It is concluded that the treatment of RDF of NPK + vermicompost@5 t/ha + Azotobacter @5 Kg/ha + PSB @5 $\mathrm{Kg} / \mathrm{ha}$ had maximum number of fruits per plant, yield per plant and yield per plot. Moreover this treatment took minimum days to anthesis of first female flower and days to first picking, also had maximum fruit length, fruit girth and fruit weight as compared to the other treatments. RDF of NPK + vermicompost @5 t/ha + Azotobacter@5 Kg/ha + PSB @5 $\mathrm{Kg} / \mathrm{ha}$ is the best integrated nutrient management approach for yield and related characters for protected cultivation of cucumber under Punjab conditions.

\section{References}

1. Gopalkrishnan TR. Cucurbits In: Vegetable crops. New India Publishing 2007, 103.

2. Tekale CD, Tumbare AD, Tekale GS, Danawale NJ and Tambe ST. Effect of different fertigation levels and schedules on growth and yield of cucumber under polyhouse condition. International Journal of Current Research 2014; 6(7):7353-7355.

3. Dhillon NS, Sharma P, Sharma KD, Kumar P. Effect of plant density and shoot pruning on yield and quality of polyhouse grown cucumber. Environment and Ecology 2017;35:3023-3026.

4. Jilani MS, Bakar A, Waseem K, Kiran M. Effect of different levels of NPK on the growth and yield of cucumber (Cucumis sativus L.) under the plastic tunnel. Journal of Agriculture and Social Sciences 2009;5(3):99101.

5. Natsheh B, Mousa S. Effect of organic and inorganic fertilizers application on soil and cucumber (Cucumis sativa L.) plant productivity. International Journal of Agriculture and Forestry 2014;4(3):166-170.

6. Thriveni V, Mishra HN, Pattanayak SK, Sahoo GS, Thomson T. Effect of inorganic, organic fertilizers and bio fertilizers on growth, flowering, yield and quality attributes of bitter gourd (Momordica charantia L.). International Journal of Farm Sciences 2015;5(1):24-29.

7. Kumar M, Chaudhary V, Naresh RK, Maurya OP, Pal SL. Does integrated sources of nutrients enhance growth, yield and quality and soil fertility of vegetable crops? International Journal of Current Microbiology and Applied Science 2018;7(6):125-155.

8. Singh J, Singh MK, Kumar M, Kumar V, Singh KP, Omid AQ. Effect of integrated nutrient management on growth, flowering and yield attributes of cucumber (Cucumis sativus L.). International Journal of Chemical Studies 2018;6(4):567-572.

9. Moharana DP, Mohan L, Singh BK, Singh AK, Kumar H, Mahapatra AS. Effect of integrated nutrient management on growth and yield attributes of cucumber (Cucumis sativus L.) cv. Swarna Ageti under polyhouse conditions. The Bioscan 2017;12(1):305-308.

10. Singh L. Effect of integrated nutrient management on growth, yield and quality traits of cucumber (Cucumis sativus L.) $c v$. Swarna Ageti under polyhouse condition. M.Sc. Thesis, Submitted to Banaras Hindu University, Varanasi, India 2016.

11. Arun R, Kumar RJ. Influence of nutrient management system on yield attributes of cucumber (Cucumis sativus L. var. Beit Alpha) cultivated in polyhouse conditions. Trends in Bioscience 2014;7(21):3450-3452.

12. Prabhu M, Natarajan S, Srinivasan K, Pugalendhi L. Integrated nutrient management in cucumber. Indian Journal of Agriculture Research 2006;40(2):123-126.

13. Choudhari SM, More TA. Fertigation, fertilizer and spacing requirement of tropical gynoecious cucumber hybrids. Acta Horticulture 2002;588:233-240.

14. Patle BJ, Wagh AP, Umbarkar PS, Bondre SV. Integrated nutrient management studies in bottle gourd. Journal of Pharmacognosy and Phytochemistry 2018;7(5):13831385. 